\title{
Does the public have a role in forest management? Canadian and U.S. perspectives ${ }^{1}$
}

\author{
By Bruce Shindler ${ }^{2}$
}

\section{Introduction}

When I was contacted to speak at this meeting, I asked the organizers "why the topic of public involvement? Why would the C.P.P.A. want to hear about the public's role in forest management?" The response was simply: "they know it's coming." According to my colleagues in British Columbia and Alberta, the Canadian brand of forestry I'm most familiar with, this is probably true; you do know that citizens are likely to play a larger role in forestry of the future. There is also recognition of the need to stay ahead of public pressure in order to avoid the mistakes we have made in the United States. In any case, if you think there is even a remote possibility of an expanded public role, it may be wise to learn from our shortcomings. Forestry professionals in the U.S. have made a lot of mistakes, but fortunately we have also learned quite a bit along the way.

\section{Changing Profession}

There are certainly plenty of reasons to pay attention to the great forestry debate in North America and the public's role in it. The face of modern forestry is changing, not just in how we do business but in how people think about forest management. For example, social scientists like me who monitor change in people's attitudes, values, and opinions about natural resource management have seen large scale shifts in the last 25 years. Most of you know that, in general, people now place greater emphasis on environmental protection, less emphasis on extractive activities, and prefer more holistic management over commodity outputs. For many citizens, values like fish, wildlife, recreation, and scenic quality are at least as important as wood products. And as the general public becomes more aware of natural resource issues, they have questions about the environmental risk of forest practices. Over time, trust in government and big business has decreased and citizens - at least in the U.S. - expect they can have a role in planning how resources are allocated.

In the U.S., finding solutions amidst these societal changes has not been easy. An indication that we still have a long way to go comes from a recent opinion survey we conducted in Oregon and Washington. Overall, $93 \%$ of those polled think the federal courts are among the most important players in the forest policy picture. And the key reason people are going to court is the Forest Service's failure to adequately involve the public in decisions about forest planning and timber sales.

Thus far, it appears that I have been portraying the forestry situation only from a U.S. perspective. But let's rethink this approach by looking at two comparable national surveys: the U.S. Forest Survey conducted in 1992 by me and two other

${ }^{1}$ Keynote presentation at the 79th Annual Meeting, Canadian Woodlands Forum, Canadian Pulp and Paper Association, Montreal, QC, March 22-25, 1998.

${ }^{2}$ Department of Forest Resources, Oregon State University, Corvallis, OR 97331 ,

U.S.A.Email: shindleb@ccmail.orst.edu colleagues and the 1996 Canadian Forest Survey conducted by a team of researchers from the University of Northern British Columbia (Robinson $e t$ al. 1997). In both surveys, respondents were asked whether they agreed or disagreed (or were neutral) with a series of statements about forest priorities. Their level of agreement with two statements is informative:

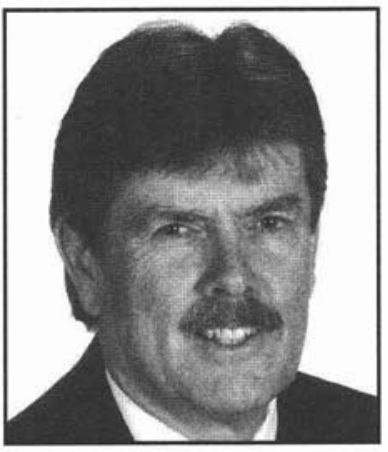

- Areas of forest should permanently be set aside for uses and values other than logging.

- The continued existence of fish, wildlife, and plant habitat is more important than harvesting trees.

On the issue of public involvement in forest management, survey participants were given a choice of various roles they might choose to play. Over two-thirds ( $72 \%$ in the U.S. and $67 \%$ in Canada) wanted citizens to play an active role where they could serve on advisory boards or be a full partner with forestry professionals in making decisions. People in both surveys were asked who policy makers should be most responsive to when setting forest management goals. The rank order of the top seven indicates a preference for increased public input:

\section{United States}

1. local affected communities 1 . local affected communities

$\begin{array}{ll}2 \text {. national public opinion } & 2 \text {. local environmental groups }\end{array}$

3. government resource agencies

4. local environmental groups

5. local affected industry

6. state public opinion

7. international public opinion

3. local affected First Nations groups

4. provincial/national environmental groups

5. provincial public opinion

6. local affected industry

7. government resource agencies

Finally, a statement from the Canadian Forest Survey's executive summary provides particular insight on the Canadian perspective (Robinson et al. 1997):

Overall, the opinions of local, provincial, and national groups were very similar on the role the public should play in setting forest management goals, and again clearly demonstrate the public's desire that Canadians should be meaningfully involved in deciding how their public forests should be managed. A lack of confidence felt by the Canadian public in government resource professionals to 
protect and manage for a broad array of forest values may contribute to the important roles that the majority of local, provincial, and national respondents believe the Canadian public should have in forest management. These findings suggest that the forest management decisions that do not involve the Canadian public in a meaningful way may not be supported by the public.

An initial reaction to these survey findings might be to think they are dominated by urban residents. However, a more recent Canadian study sheds light on responses specifically from citizens in a wood-producing region. I have a doctoral student from Montreal studying with me at Oregon State University whose research is in the Haut-St-Maurice Region of Quebec. She interviewed residents of forest communities about their ability to respond to shifts in forest industry and policy in their area. First, all were willing to participate - even happy to be asked - and many had good insights about their community's present and future conditions. Furthermore, a large scale mail survey of this timber producing region's residents showed evidence of preferences for a wide range of forest values. Three quarters $(75 \%)$ of those surveyed believe that managers should attach the same importance to all forest resources when setting priorities.

\section{Public Role}

So we return to our original question: does the public have a role in forest management? Those of us here - forest professionals, managers, scientists - may not be the ones to determine the answer to this question. Ultimately, it may be the citizens themselves. We can see this is true when we recognize that there are two types of power in public lands management. First is legal or jurisdictional power. This is the power granted to natural resource agencies to carry out laws and enforce forest policies. The second is political power which is maintained by citizens. People exercise their political power by supporting the management status quo or by changing those in jurisdictional power (or even by changing the laws) when they disagree strongly enough with the way business is being conducted. We only need to look at U.S. forest policy of the last 25 years to see this latter phenomenon in action.

Accounting for public perspectives becomes increasingly important when we understand the role that people play in longterm management of forests. For example, Walter Firey in Man, Mind, and Land (1960) identified three key requisites to explain why certain resource practices and systems persisted. These included:

1. Physically possible: practices were consistent with ecological processes.

2. Economically feasible: practices generated revenue in excess of costs.

3. Culturally adoptable: practices were consistent with prevailing social customs and norms.

Firey's notion of "culturally adoptable" is generally consistent with the notion of forest management that is acceptable to the public. The essential premise is that even if practices are physically possible and economically feasible, they still stand little chance of successful implementation if they lack acceptance by the wider community. Indeed, these three criteria are mutually constraining and each is necessary.

\section{Likely Outcomes of Public Involvement}

The question of whether we should involve the public in forest management requires that we look at the likely outcomes of doing so. From experiences in agency/citizen interactions, managers and researchers generally agree that effective public involvement can result in a number of useful outcomes:

- identifies public concerns about natural resources

- helps determine public preferences for management policies

- provides an early warning system for potential controversy

- taps local knowledge about resource use and management

- encourages mutual learning among participants

- provides method for reaching agreement (or acceptance)

- legitimizes actions and decisions

- builds trust in government agencies

- produces more durable decisions

- failure to do so leads public to choose other forums for resolving concerns (media, legislature, courts)

At the same time, it is also recognized there are potential shortcomings to involving the public:

- requires knowledge of the issues by participants

- reaching decisions takes more time and is hard work

- people can get burned out from meetings and discussion

- requires skilled staff to implement properly

\section{Strategies}

Having described a rationale for public involvement and some likely outcomes, what strategies can I leave with you for implementation? Overall, one strategy is most essential and is the key to all others. Although a number of people have recognized this planning tool, the Canadian group at the Banff Centre School for Management probably has brought the most attention to it. The technique is simply called "up-front thinking" (Delli Priscolli and Homenuck 1990). This strategy warns that there are important management considerations prior to engaging the public. Organizational personnel must think through and agree on a plan for involving citizens. This includes addressing questions such as:

\section{How will decisions be made?}

What do we hope to accomplish by involving the public? What is the public's role in this discussion?

What do they need to know to participate?

Who is "the public" for this issue?

The up-front thinking technique is important because it forces organizations to discuss objectives and come to agreement about the public's role. Careful consideration to this initial planning step helps agencies organize themselves to be successful and avoid costly problems later on.

A second strategy recognizes that if citizens are going to have a role, they will be more useful if they are knowledgeable about the choices involved. We all know that many people representing special interest groups already have their opinions well formed. Although very vocal, they represent a fairly small percentage of people overall. What about everyone else? How do you want the growing number of interested citizens to form their opinions on what good forest management is? More and more, people are deciding to take an interest in forest management activities - you can either sit back and wait for them to show 
up, or you can help provide places and forums for them to become better informed about the complexities of forest management. This includes creating open and honest discussion about the tough tradeoffs that come with making one choice over another.

This involvement strategy will require a different way of thinking for most of us. Forestry professionals have always done a good job of providing information about visitor services such as recreation places or tourism activities. However, we have done very little over the years to help people understand forest conditions and management, nor have we done much to understand what affected citizens know about forest practices. Traditionally, we see ourselves as information providers, not discussion leaders. Recently, however, local outreach efforts have begun to emerge. For example, in my home town forest industry comes to the community's fall festival to showcase the uses and importance of timber-including a place for children and parents to build scale-model homes out of wood products. Forest industry also has a presence in the Portland, Oregon public schools, where volunteers provide an in-class program on forestry and the environment to elementary students.

Similarly, forest agencies have begun to address people's interest in the broader forest spectrum. Facilities in British Columbia, Washington, and Oregon are now using interpretive centers and trails to describe ecosystem management practices to forest visitors. In addition, agencies have begun producing brochures, pamphlets, web sites, and even local video programs on specific practices such as prescribed fire and mechanized thinning. More important, perhaps, is the recognition that we need places and forums to openly discuss the choices, tradeoffs, and outcomes of managing forests. For example, in my home state of Oregon forest agencies have created several demonstration sites where private and public forestry professionals meet with citizens to view and discuss management options. Feedback from participants suggest this is a good way to learn from one another and examine meaningful alternatives.

\section{Conclusion}

As managers and scientists, we clearly have a choice in how we interact with citizens and what role we are willing to let the public play in forest management. In illustration, I would like to end my talk today with contrasting stories about two people facing these same choices. The first involves a consultant who conducted a study about the public's view of forest management for the California Forestry Association in the early 1990's (Wilson 1991). The work is noteworthy because several western states had just begun to require scenic corridors (tree buffers) along state highways in forested areas. At the conclusion of his study, the consultant recommended that the public's visit to the forest should be treated like a trip to Disneyland.
He advocated keeping people on the highway or in recreation areas; that is, "we should never let them see Mickey Mouse take off his head." As long as we can keep people from seeing the machines, gears, pulleys, and the business side of forestry, we can keep the myth of forestry alive. His premise was that as long as we don't talk about logging, the public will continue to see the forest as a happy, beautiful place to visit.

The second perspective is from a colleague at the University Colorado who wrote a piece while we were working together on the public perspectives of global change. Our specific interest was in how the U.S. Forest Service might respond to people and what type of leadership role the agency should take regarding national forests. Dale Jamieson wrote (1994):

Competence needs to be developed both within the Forest Service and in the communities with which the Forest Service enters into dialogue. In the bad old days there was a tendency for government agencies to dictate policy to citizens. These days there is a tendency for citizens to try to dictate policy to government agencies. There is an admission price for engaging in a public dialogue. Part of the price is purely formal: to treat others with respect, to be sympathetic to alternative points of view, to strive for impartiality, and so on. Part of the admission price also involves knowing something substantive about the issues: the relevant science, the economics, the values and interests that are at stake. People do not come with a ready-made ability to engage in constructive, deliberative discussion. The Forest Service should do what it can to develop its own competence for engaging in this dialogue, but it also should contribute to developing the competence of those with whom it engages. Only then will the turn toward public participation be mutually educational.

Instead of asking does the public have a role in forest management, we should consider what kind of role it will be. At this point, the choice is still ours.

\section{References}

Delli Priscolli, J. and P. Homenuck. 1990. Consulting the publics. In R. Lang (ed.). Integrated approaches to resource planning and management. pp 67-80. Banff Centre School of Management, Banff, AB. Firey, W. 1960. Man, mind, and land: a theory of resource use. The Free Press of Glencoe. Glencoe, IL.

Jamieson, D. 1994. Problems and prospects for a Forest Service program in the human dimensions of global change. In K. Geyer and B. Shindler (eds.). Breaking the mold: global change, social responsibility, and natural resource policy. pp 23-28. Oregon State University, Corvallis, OR.

Robinson, D., A. Hawley, and M. Robson. 1997. Assessing Canadian public opinion on forest values and forest management (draft): results of the Canadian Forest Survey '96. McGregor Model Forest Association, Prince George, BC.

Wilson, A. 1991. Seeing through their eyes. Pacific Forests 4(3): 30-31. 